\title{
The 14 August 1708 Manosque, France earthquake: new constraints on the damage area from in-depth historical studies
}

\author{
Grégory Quenet $\left({ }^{1}\right)$, David Baumont $\left({ }^{2}\right)$, Oona Scotti $\left({ }^{2}\right)$ and Agnès Levret $\left(^{3}\right)$ \\ ${ }^{1}$ ) Département d'Histoire, Université de Versailles-St-Quentin-en-Yvelines, Guyancourt, France \\ ${ }^{2}{ }^{2}$ Institut de Radioprotection et de Sûreté Nucléaire, Fontenay-aux-Roses, France
}

$\left({ }^{3}\right)$ Groupe APS, Site de Ruscino, Château-Roussillon, Perpignan, France

\begin{abstract}
In this paper, we re-evaluate the damage area of the 14 August 1708 Manosque earthquake, Southeast France. It is the strongest event $\left(I_{o}=\right.$ VIII MSK) of a seismic sequence that lasted from March to October 1708. We show that the spatial repartition of the damage that can be proposed based on the existing sources, is clearly biased by the abundant narrative information concerning Manosque. This sparseness in the information can be attributed to differences in communication routes or strategies between the different localities, and affects the global perception of the event, especially in the rural area. To tackle this bias, we propose to inventory the building repairs reported in non-narrative sources in order to capture the effects of the Manosque earthquake in the surrounding region. The debates and accounts (between mid-1708 and 1710) show that moderate to heavy repairs consistently affect localities in the epicentral area, covering a region of at least $12 \mathrm{~km}$ radius around Manosque. These building repairs, indirectly attesting to earthquake damage, provide valuable and complementary information, which resulted in a better knowledge of this event. In particular, we propose new intensity estimates $(I>V I)$ at six localities.
\end{abstract}

Key words historical earthquakes - non-narrative sources - damage area - building repairs

\section{Introduction}

The SISFRANCE project aimed to establish the most exhaustive intensity and documentary database for historical earthquakes felt in France (Lambert et al., 1997). In spite of the enormous effort that has been made for the past 30 years, numerous earthquakes remain for which

Mailing address: Dr. Grégory Quenet, Département d'Histoire, Université de Versailles-St-Quentin-en-Yvelines, 47, boulevard Vauban, 78047 Guyancourt, France; e-mail: gregory.quenet@free.fr either no epicentral intensity evaluation is possible $(50 \%)$ or the damage area is only known on the basis of a few observation points (see Scotti et al., this issue).

The 14 August 1708 Manosque earthquake occurred along the Durance fault, southern France, the site of a relatively high rate of damaging earthquakes (comparable events occurred in $1509,1708,1812,1913$ ) (fig. 1). It is the strongest event of a seismic sequence that lasted from March to October 1708 (http://www.sis france.net). In Perrey's catalogue, dating from the mid 19th century, the Manosque quake was known only through two unreliable secondary sources, giving an incorrect date and mentioning «flames coming out of the ground» (Perrey, 1845). Vogt $(1981 ; 1993)$, in the framework of 


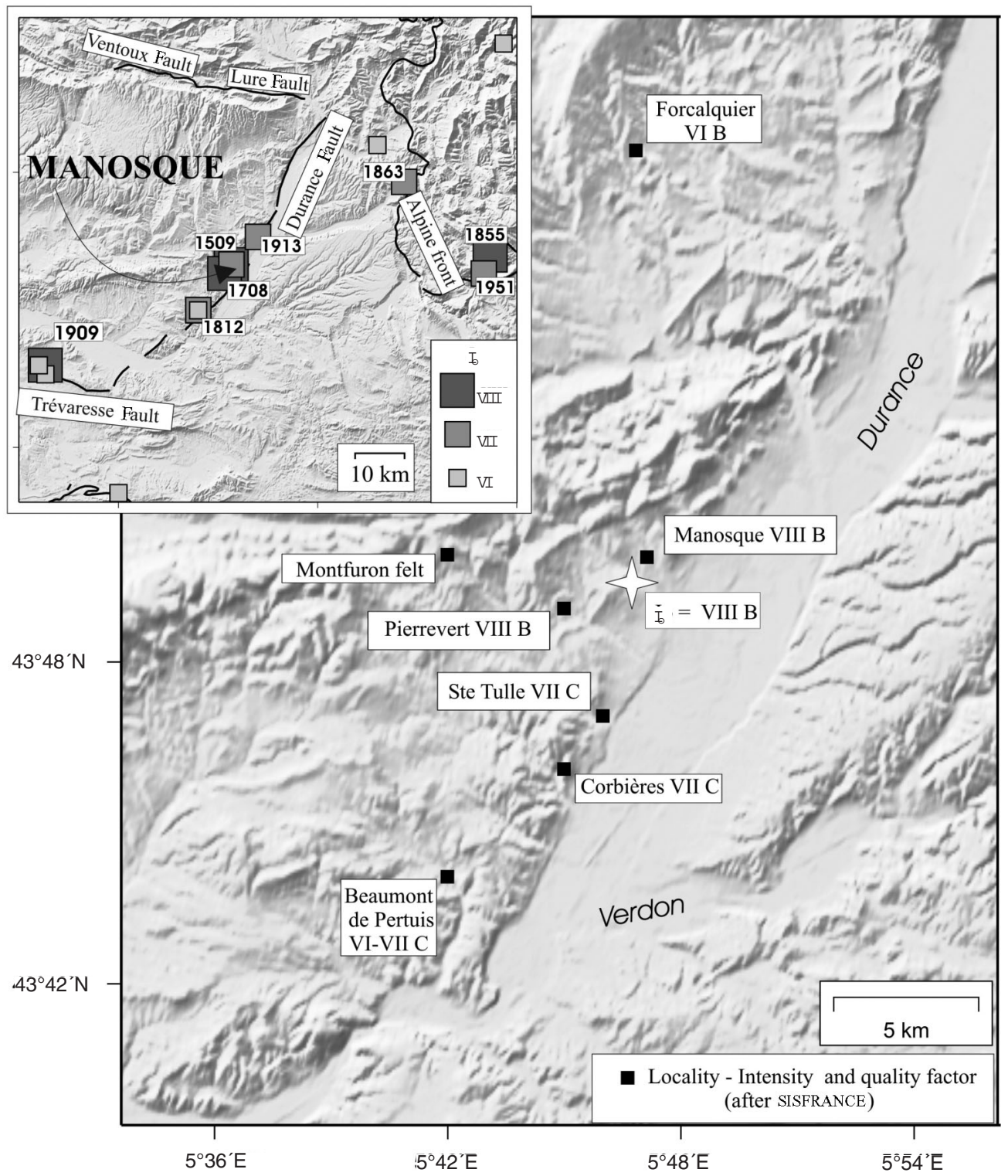

Fig. 1. Map showing estimated intensities for the 14 August 1708 Manosque earthquake taken from the SISFRANCE database. This event is only known on the basis of a few intensity points. The macroseismic epicentre (star) is located halfway between Manosque and Pierrevert with an epicentral intensity of VIII (fairly well constrained). Inset: Historical seismicity $\left(I_{o} \geq \mathrm{VI}\right)$ and the simplified fault map in the region of the 1708 Manosque earthquake. This region is characterized by a regular moderate seismicity that localizes along the Durance fault. The location of the 1909 Lambesc event on the Trévaresse Fault is also shown as well as the seismicity of the Alpine front to the east. 
SISFRANCE (formerly SIRENE), provided the first historical studies concerning the Durance fault events. In 1998, when the research presented in this paper started, the SISFRANCE database listed 32 references concerning 18 localities. The damage area ( $I>$ VI - MSK 1964) was known on the basis of 5 observation points: $I=\mathrm{VIII}$ at Manosque and Pierrevert (quality B, fairly constrained), $I=$ VII at Corbières and Sainte Tulle and $I$ $=$ VI-VII at Beaumont de Pertuis, (all of quality $\mathrm{C}$, poorly constrained). The epicentre $\left(I_{o}=\mathrm{VIII}\right)$ was located roughly midway between Manosque and Pierrevert (fig. 1). Although only a few intensity points are available, it is possible to roughly estimate the earthquake magnitude at around 5 and its depth at less than $5 \mathrm{~km}$, but with a very low level of confidence.

In order to increase our confidence in the magnitude estimates, in this paper we re-eva- luate the effects of the earthquake, especially in the rural regions, through an in-depth historical analysis of existing and new documentary sources.

\section{An updated hierarchical organization of the sources}

One of the first difficulties we faced at the beginning of this study was the re-appraisal and tracing of the sources used in previous historical studies. Vogt (1981), for example, who was the first to work on the Manosque event, used a printed edition of the correspondence to the comptroller general of finances (Boislile, 1897). However, the printed edition only provides an extract of the original, located in the $\mathrm{Na}-$ tional Archives (AN Paris, 1708-1709). This

Table I. Example of the SISFRANCE referencing scheme for the 14 August 1708, Manosque earthquake (extracted from www.sisfrance.net in 2002).

\begin{tabular}{|c|c|c|c|c|c|}
\hline Author & Article & References & Séries & Edition & $\begin{array}{c}\text { Publication } \\
\text { date }\end{array}$ \\
\hline J.P. Rothé & $\begin{array}{l}\text { Les séismes des } \\
\text { Alpes françaises } \\
\text { en } 1938 \text { et la séi- } \\
\text { smicité des Alpes } \\
\text { occidentales }\end{array}$ & $\begin{array}{l}\text { Annales } 1938, \\
\text { Inst. Physique du } \\
\text { Globe de Strasbourg }\end{array}$ & $\begin{array}{l}\text { T 3, } \\
\text { géophysi- } \\
\text { que }\end{array}$ & Mende & 1941 \\
\hline C. Bernard & & $\begin{array}{l}\text { Essai historique } \\
\text { sur la ville } \\
\text { de Forcalquier }\end{array}$ & & Forcalquier & 1904 \\
\hline $\begin{array}{l}\text { A. Feraud } \\
\text { (abbé) }\end{array}$ & & $\begin{array}{l}\text { Histoire civile, } \\
\text { politique, religieuse } \\
\text { et biographique } \\
\text { de Manosque }\end{array}$ & & Digne & 1848 \\
\hline $\begin{array}{c}\text { J.B.C. } \\
\text { Surrach (de) }\end{array}$ & $\begin{array}{l}\text { Livre de raison de } \\
\text { Jean-Baptiste- } \\
\text { Charles de Surrach } \\
(1706-1754)\end{array}$ & $\begin{array}{l}\text { Inventaire imprimé. } \\
\text { Arch. Dept. Vaucluse }\end{array}$ & $\begin{array}{l}\text { Série h 6, } \\
\text { hospice de } \\
\text { Bédarrides }\end{array}$ & & \\
\hline J.M. Robert & & $\begin{array}{l}\text { Notice historique sur } \\
\text { le tremblement de } \\
\text { terre du village de } \\
\text { Beaumont (Vaucluse) }\end{array}$ & & $\begin{array}{l}\text { Aix-en- } \\
\text { Provence }\end{array}$ & Juillet 1812 \\
\hline
\end{tabular}




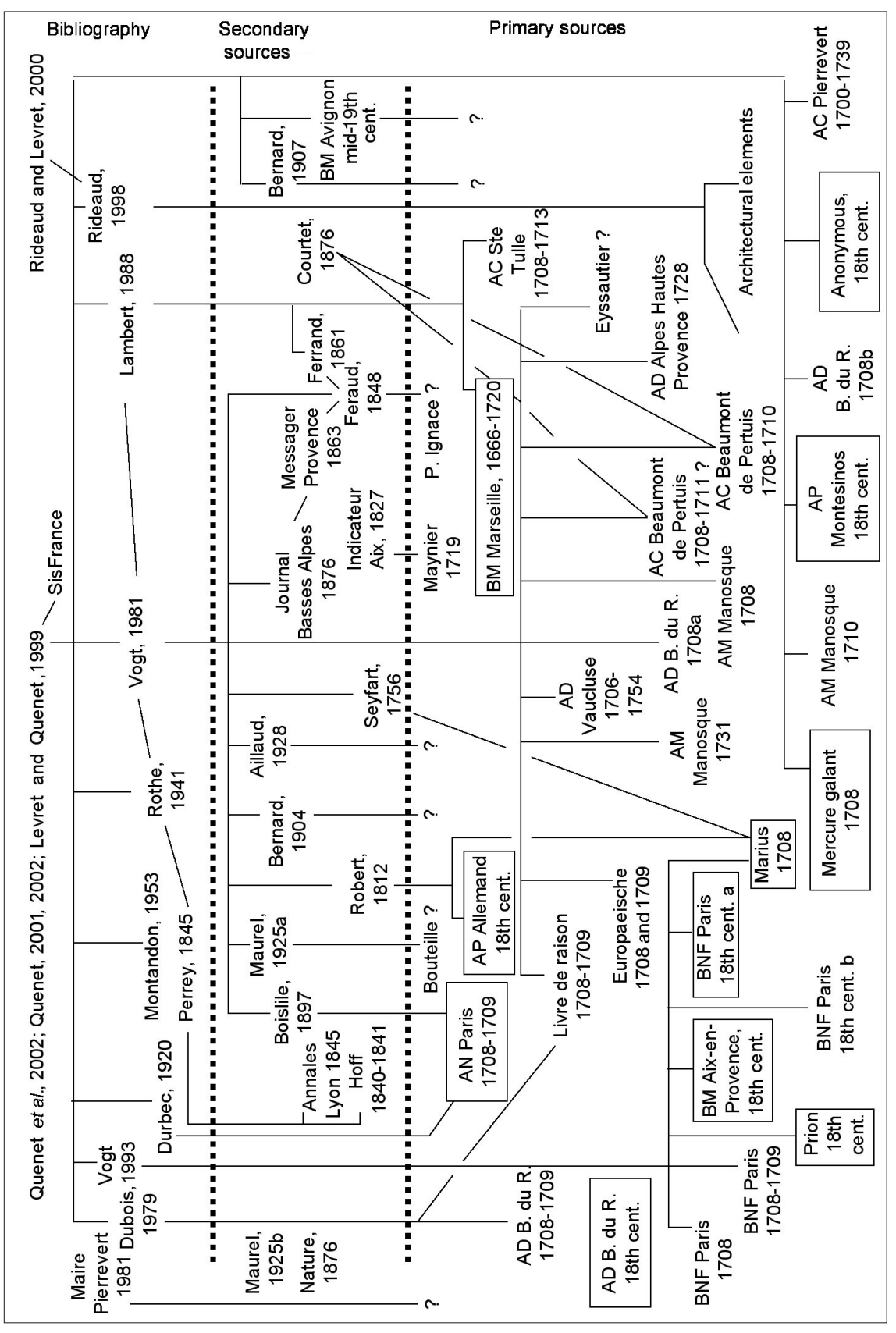

这完

$\sum$ क

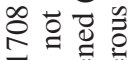

o

on

可

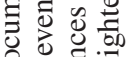

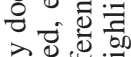

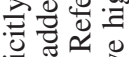

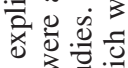

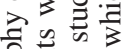

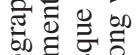

응 훙 응

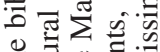

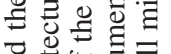

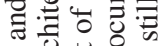

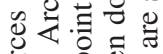

言品. 可

르을

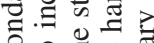

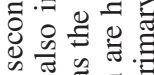

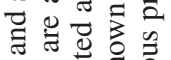

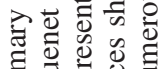

艺橧

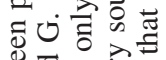

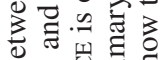

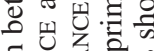

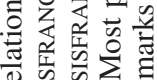
क

on

F

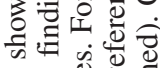

过过

न

긍

牙

i $5 . \bar{\sigma}$

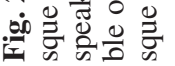


original document is much more complete, since it contains an additional paragraph, highlighting the historical context of the text. It also contains an unknown letter, used in this study, reporting damage caused by the earthquake in the village of Pierrevert. More recently, SISFRANCE proposed for this event a list of 32 references as well as the digitalized copies of the sources (see an extraction in table I). However, the documentary references are not differentiated according to their nature. For example, the Livre de raison de Jean-Baptiste-Charles de Surrach (AD Vaucluse, 1706-1754) is a primary source, a material contemporary to the Manosque event. On the other hand, the Histoire civile, politique, religieuse et biographique de Manosque written by Feraud and published in 1848 , is a secondary source, which offers an analysis or a restatement of primary sources. Finally, Rothé (1941) is a seismological study that belongs to the bibliography, which contains all the studies relying on the documentary sources. Last but not least, systematic referencing of the historical seismicity studies is not provided in SISFRANCE. For example Vogt $(1981 ; 1993)$ are not referenced, although they quote a manuscript (BM Aix-en-Provence, 18th cent.) that was not listed in SISFRANCE at the beginning of this study.

In an attempt to eliminate doubles and to identify new routes of research, Quenet (2002) proposed a hierarchical organisation of the sources, which is updated in fig. 2. It shows that the most recent seismological studies (Vogt, 1981, 1993; Lambert, 1988) already quoted most of the sources known today, although numerous documents known to exist remain to be found. Some local documentary sources (AD B. du R., 17081709 and 1708a) mentioned that the city of Manosque sent representatives to a regional institution - the «Etats de Provence» - in order to get a tax rebate due to the consequences of the earthquake (Dubois, 1979; Vogt, 1981), suggesting the existence of a document describing the effects of the earthquake in Manosque. Indeed, this led us to the discovery (Quenet, 2001, 2002) of a very detailed damage survey made a few days after the event (AD B. du R., 1708b) and written by bricklayers seven months after the catastrophe. It reports on the damage caused by the earthquake on 740 buildings in the city of Manosque (including owner's name, building type, detailed damage, and cost of repairs).

Thanks to this hierarchical organization, the source databank is now available with a consistent level of exigency but most importantly new sources were found, that will allow us to shed new light on the perception of this event.

\section{Analysis of communication to explain the sparse data}

The next step in our study was to interpret each document in its historical context. Indeed, a source is always a trace and never a mirror from the past (Veyne, 1979) and thus even the most precise text is biased. To generalize from one document to the general effects of an earthquake and to interpret the non-explicit meaning of a source it is necessary to consider the historical context. Details of this work were partly presented in Quenet (2002).

Here we focus the attention of the reader on the importance of analysing communication routes for a more complete understanding of the 1708 earthquake. Figure 2 shows that there are many accounts of the 1708 earthquake, which are largely devoted to the city of Manosque. They are long, very similar in style and content, and appear to be different versions of a single manuscript. These accounts had a great impact because some of them were kept in Paris, published in national periodicals and were translated into German. On the other hand, only a few sources are available for neighbouring localities (see also the reference list and table IIA).

This disparity may reflect a much higher level of damage in the city of Manosque, however, as shown by debates in the town council (AM Manosque, 1708-1709), this disparity may also result from the strategy of Manosque facing the catastrophe. Manosque authorities requested written accounts of the quake. They then asked influential personalities (the archbishop of Aix-en-Provence, the governor of Provence, the bishop of Sisteron, brother of the comptroller general of finances, etc.) to deliver these accounts directly to the King in the hope of obtaining tax reduc- 
tions. Moreover, the contemporaries produced several other versions by recopying these accounts, contributing to accentuate this disparity. Pierrevert, on the other hand, located only five kilometres away from Manosque, was also severely damaged (see table IIA). But, this small village did not have the means of Manosque and could not follow the same strategy (Quenet, 2001, 2002). In addition, the city of Manosque, struggling to preserve its status as a free city against the counts of Forcalquier (Quenet, 2001, 2002), conserved the archives very early on, in order to prove the rights of its inhabitants. The resulting exceptional quality of the archives may also account for the observed disparity.

The organisation of the territory is an additional factor inducing a spatially heterogeneous repartition of the sources. The left bank of the river Durance is sparsely populated between the river and the town of Valensole (fig. 3). The presence of only a few isolated human settlements is aggravated by the serious demographic regression that occurred in the 18th century. The river Durance is a natural barrier separating the two banks. Floods are a danger; the two banks are scarcely practicable. The orientation of the paths of communication reinforces this dead end for the socialisation of space, especially for isolated communities (Emmanuelli, 1974).

We can therefore conclude that the high spatial concentration of the information (macrocephalic data) can be partially explained by differences in communication about quakes and by the organisation of the territory, and thus should not be attributed to differences in damage only.

\section{Non-narrative sources: a key to by-pass sparse data}

Previous historical seismicity studies were based on the analysis of sources that explicitly ascribe the relation of the effects to the occurrence of a past earthquake. Consequently, they rely mostly on narrative sources (i.e. texts in prose or verse written in order to describe the past in a narrative way: annals, chronicles, letters, diaries, poems, saint's lives, genealogies, etc.). The non-narrative sources were thus poorly exploited (i.e. any document which does not relate events but records a decision made by an individual or an institution: deliberations, accounts, etc.) since the word earthquake is often missing in them. Nevertheless, we will show that through a systematic investigation, non-narrative sources can illuminate and improve our knowledge of the damage area.

\subsection{Is there a significant increase in building repairs following the 1708 Manosque earthquake?}

We consulted the archives of the communes located in the region of Manosque (restricted to the Departement des Alpes de Haute Provence) to trace the building repairs reported in the debates and accounts between 1707 and 1710. We focused our research within a zone of $20 \mathrm{~km}$ radius around Manosque. Among the 29 localities selected (fig. 3), 20 of them possess archives for our period of interest, which is rare in France. Whereas very few building repairs are reported before the Manosque earthquake, 9 localities (Beaumont de Pertuis, Montfuron, Pierrevert, St. Tulle, St. Maime, St. Martin les Eaux, St. Michel l'Observatoire, Villemus, and Villeneuve) carried out building repairs (to at least two buildings) between mid-august 1708 and the end of 1710. For instance, in St.-Maime, the authorities repaired the forge and blacksmith's house, the retting building, the wall of the cemetery, the common house, the oratory and the church (AC St.-Maime, 1674-1720) (see table IIA for references attesting to the existence of these repairs). In eight more localities, Allemagne en Provence, Esparron de Verdon, Gréouxles-bains, Mane, Niozelles, Saint Martin de Bromes, and Valensole, either no building repairs are reported after the Manosque event (AC Allemagne en Provence, 1673-1710; AC Esparron de Verdon, 1682-1738; AC Gréouxles-bains, 1708-1709; AC Mane, 1708-1710; AC Niozelles, 1707-1733; AC Valensole, 17081710), or they are due to heavy rains, as clearly mentioned in the deliberation in Saint Martin de Bromes (AC Saint Martin de Bromes, 1708- 


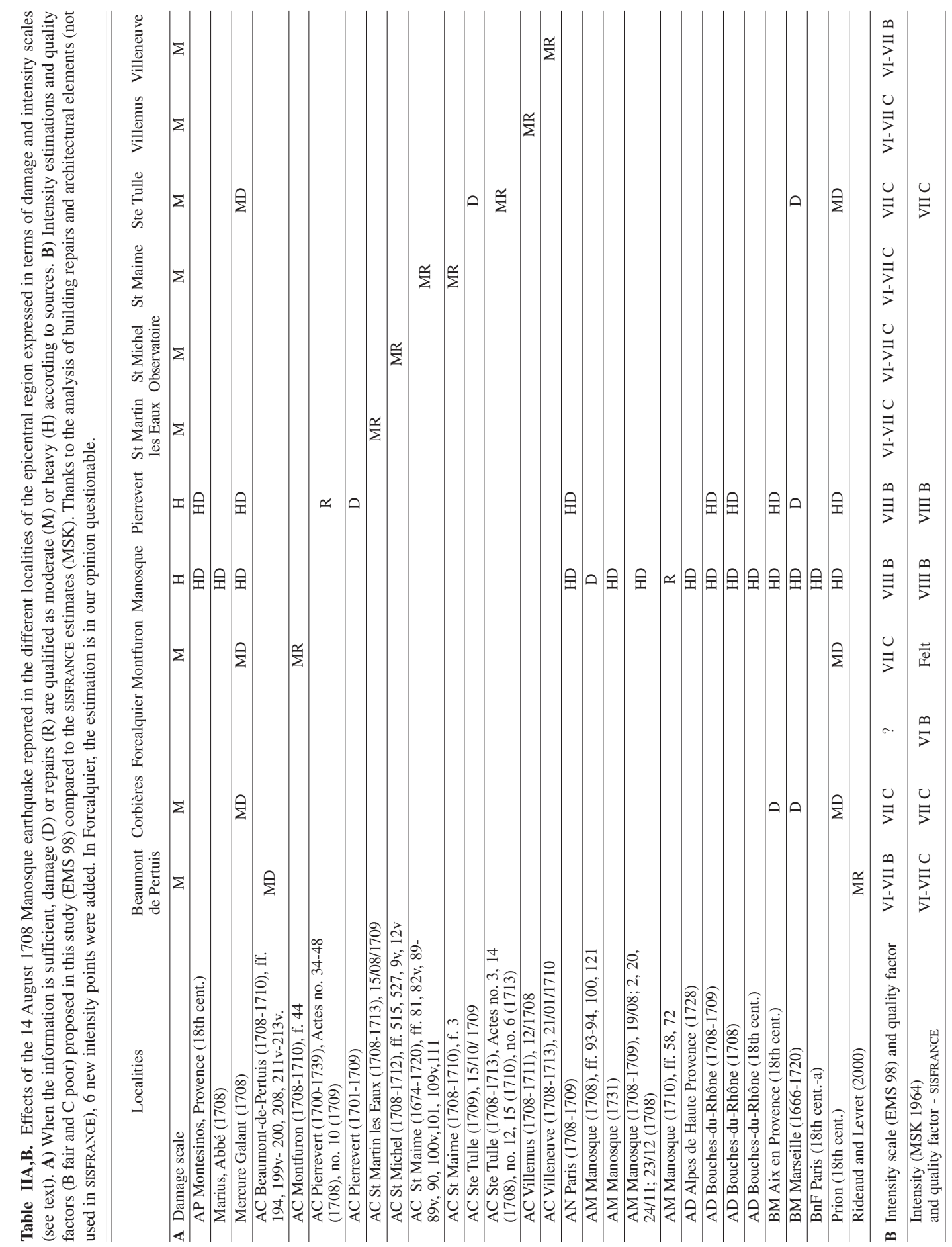




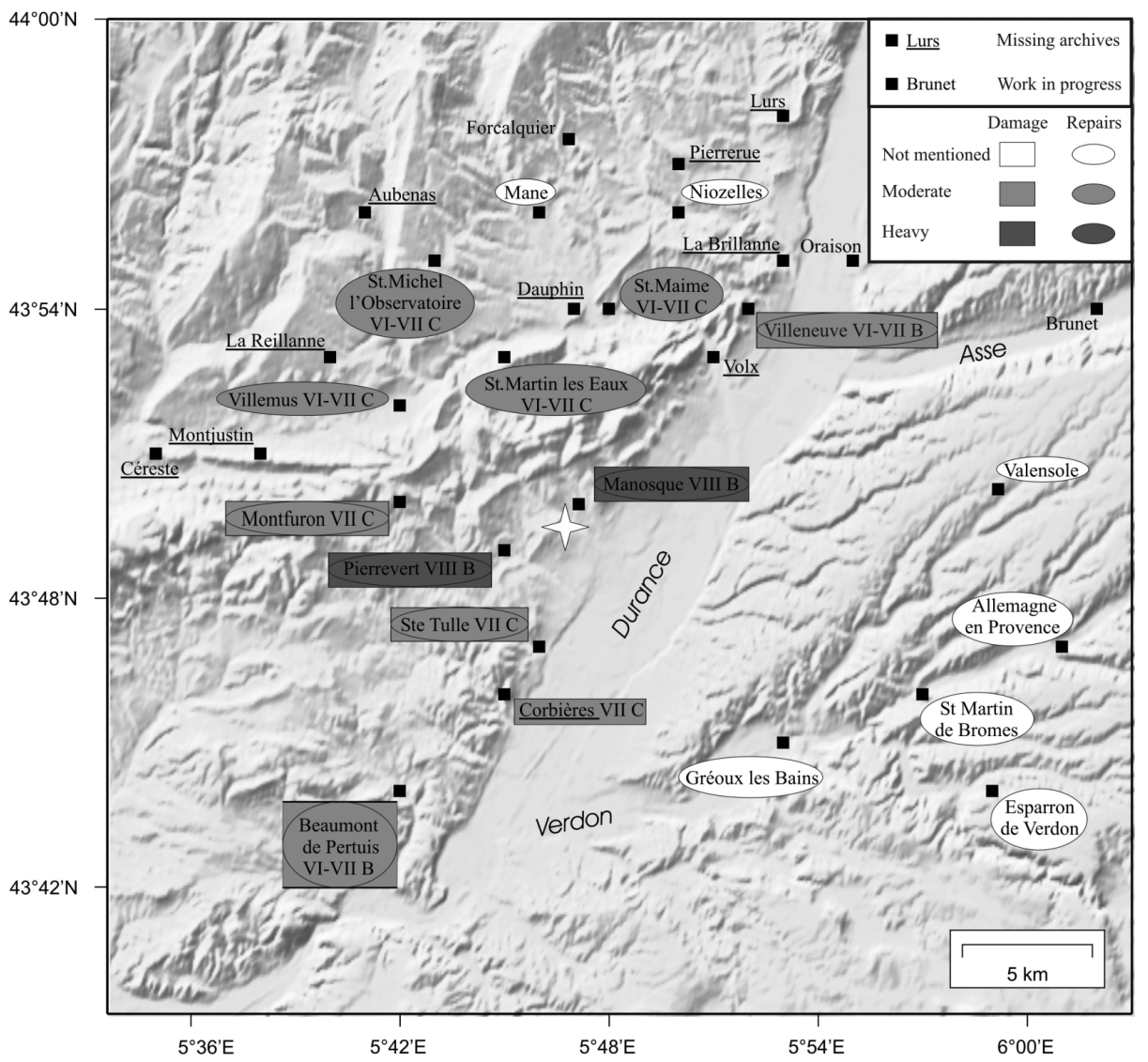

Fig. 3. Map showing the effects of the 14 August 1708 Manosque earthquake in the epicentral area estimated (table II) from both damage (squares) and repairs (ellipses). Based on this new data set, the damage area is further increased to the north ( $c f$. fig. 1) by the addition of data in Montfuron, Villemus, St. Martin les Eaux, St. Michel l'Observatoire, St. Maime and Villeneuve. The epicenter (star) is taken from SISFRANCE.

1713). For the case of Brunet, although a text mentions the payment in December 1708 for repairs to a church (AC Brunet, 1708a,b), it also reports on the fact that this community suffered from thunderstorms without giving details on the nature of the damage (to harvest or buildings).

The interpretation of this case remains uncertain. In Oraison and Forcalquier, no building repairs were reported after the 14 August 1708, Manosque earthquake (AC Forcalquier, 1708; AC Oraison, 1708), however only the archives of the year 1708 were consulted. As shown in fig. 3, the left bank of the Durance remains poorly documented because it was sparsely populated. It should also be noticed here that the archives of the villages located to the south and west of Beaumont de Pertuis, belong to an administrative department not yet investigated. Nonetheless, fig. 3 shows that all the localities within a zone of about $12 \mathrm{~km}$ radius around Manosque, for which the archives were not missing, carried out building repairs in the two years following the earthquake. 


\subsection{Are the repairs due to earthquake damage?}

First of all, we must consider that the repairs were carried out in a period of famine (caused by the harsh winter of 1709), and thus they must have been motivated by an exceptional event (Quenet, 2001, 2002). The authorities of SaintMaime decided to repair seven buildings while, at the same time, they were thinking about requisitioning wheat because people were dying of hunger (AC St.-Maime, 1674-1720). The famine may have thus overshadowed another disaster, as is described to have happened on similar occasions in Italy (Mariotti et al., 2000). In the year 1708, two natural phenomena are reported in the region that may account for a concomitant action motivating the repairs: heavy rains and the Manosque earthquake sequence. Since in most cases, the heavy rains can hardly explain the repaired buildings, which are not located near a river or in a landslide area, the earthquake is the most likely candidate. Nevertheless, heavy rains may have contributed to the degradation of the buildings. Recent findings in three localities support our interpretation in favour of the earthquake:

i) The accounts concerning Pierrevert for the year 1708 made no mention of the earthquake whilst noting 8 re-embursement for repairs (AC Pierrevert, 1700-1739). However, a damage survey (AD B. du R., 1708b) allows us to put down these repairs to the quake.

ii) In Villeneuve, the non-narrative sources report in 1710 the re-imbursement of a mason for the purchase of a significant amount of roof tiles and a beam to repair the roofs of the forge and church (AC Villeneuve, 1708-1713). The recent discovery of a new narrative source (Anonymous, 18 th century) clearly establishes that during the 1708 Manosque earthquake, a few chimneys and roof tiles were pushed over, and thus confirmed our interpretation.

iii) The authorities in Saint-Martin les Eaux report on the payment of several repairs on the church and the claustral house (AC St Martin les Eaux, 1708-1713). Moreover, an ongoing architectural study on this building (Rideaud and Poursoulis, personal communication) shows traces of earthquake damage and repairs, the repairs being partially reported in the deliberations. At least two reasons can be invoked to explain the lack of evidence (documenting damage/repairs) for the eleven remaining localities: either the damage concerns only private houses and is not reported, or it is negligible.

Concerning the few building repairs that were carried out before the mid-August event, some of them may result from damage caused by the 21 March earthquake. For instance, in Oraison, on 25 March 1708, the authorities asked for repairs to the claustral house, the roof of a chapel and the windows of a church (AC Oraison, 1708). However, further studies are necessary before interpreting these repairs as direct consequences of an earthquake.

To conclude, in the light of these arguments, it is reasonable to interpret the building repairs as resulting from damage caused by the 1708 Manosque (fig. 3), even in the localities where descriptions of damage have not yet been found. This results in six new observation points that extend the damage area to the north of Manosque. This is in accordance with the accounts of Manosque, since they report that the 1708 earthquake had violent effects in a radius of $13 \mathrm{~km}$ around Manosque (Marius, 1708; BM Marseille, 1666-1720).

\section{Quantification of the effects of the earthquake in the epicentral region}

Quantifying the effects of the 14 August 1708 Manosque earthquake is a delicate task. Indeed, cumulative effects due to previous earthquakes and to heavy rains may potentially introduce bias. Moreover, the real number of repaired buildings in each village is most certainly higher than the few listed in communal documents or in narrative sources. This can be illustrated through the example of Pierrevert where the non-narrative communal sources only mention four repaired buildings whereas the recently found earthquake-damage survey reports damage to 161 buildings (AD B. du R., 1708b; AC Pierrevert, 1700-1739). Similarly, in Beaumont de Pertuis, the communal archives (AC Beaumont de Pertuis, 1708-1710) only document damage to the church. However, Ri- 
deaud and Levret (2000) show that not only the church but also the entire village suffered from earthquake damage based on an architectural reading of the buildings still existing today. $\mathrm{Ne}$ vertheless, we perform two quantification exercises, one expressed in terms of largest degree of damage (table IIA and fig. 3) and another in terms of intensity (table IIB and fig. 3), the latter requiring additional assumptions.

In this basic quantification exercise, we used a simplified damage classification by considering two classes; heavy when important structural damage/repairs are clearly reported and moderate otherwise. Table IIA shows the sources available for each locality and the corresponding damage estimate. In the case of insufficient information to clearly attribute a class, only damage or repairs are listed. The overall estimate for each locality is also presented (table IIA and fig. 3). According to this classification, Manosque and Pierrevert both reported heavy damage whereas Sainte Tulle, Corbières, Beaumont de Pertuis, Montfuron, Villemus, St. Martin les Eaux, St. Michel l'Observatoire, St. Maime and Villeneuve document only moderate damage. In Forcalquier, the only pertinent document available to date is the secondary source Essai historique sur la ville de Forcalquier written by Bernard (1904). It can hardly be considered in the analysis of this event because the information provided cannot be crosschecked. Moreover, the wording used by Bernard in his description of the earthquake effects in Forcalquier is very similar to the one used in manuscripts for Manosque, suggesting that Bernard (1904) may be mistaken. And thus for this village we cannot propose any estimate. This quantification exercise shows that the «moderate damaged area» extends further to the North of Manosque compared to the previous estimates of SISFRANCE (see fig. 1).

To go further in the quantification and propose intensities (table IIB and fig. 3) according to the EMS 98 (Grünthal, 1998), additional assumptions must be made (building vulnerability, damage representativeness). In Villeneuve, damage concerns five or six chimneys and few roof tiles. This description is corroborated by the building repair description, reporting that a significant amount of roof tiles and a beam we- re bought to repair the roofs of the forge and church (AC Villeneuve, 1708-1713). These few buildings with damage of degree $2-3$, probably belonging to the vulnerability class $\mathrm{A}$, led us to propose an intensity of VI-VII with a quality B (fairly constrained). In Villemus, St. Martin les Eaux, St. Michel l'Observatoire, and St. Maime, the communal resolutions and accounts report that several buildings were repaired. Most of the repairs suggest that large and extensive cracks occurred in walls, and that either roof tiles or parts of roofs fell down, indirectly attesting to the presence of moderate structural and heavy non-structural damage (degree 2-3). This is obviously too limited to attempt to apply a statistical evaluation of the intensity. Nonetheless, depending on the building typology considered (A or $\mathrm{B}$ ), the minimum value of the intensity estimate varies from VI up to VII. Yet, the intensities in these localities are unlikely to have exceeded VII according to the accounts of the overall effects of the earthquake (Mercure Galant, 1708; Prion, 18th cent.). Therefore, we propose in these four localities an intensity VI-VII with a quality $\mathrm{C}$ (poorly constrained). In Beaumont de Pertuis, the church, poorly maintained due to economic difficulties, suffered «some damage that needed to be repaired» (AC Beaumont de Pertuis, 1708-1710). Despite the consolidation repairs, the church collapsed in February 1709. The resolutions (January 1709) also report on the necessity to repair the roofs of the clock tower, communal oven, oil crusher, and communal house. Although heavy rains certainly accentuated the deterioration of the church and these four buildings, these elements strongly suggest the earthquake caused damage of degree 2-3. This is reinforced by the existence of architectural disorders and repairs in numerous buildings contemporary with the Manosque earthquake (Rideau and Levret, 2000). Assuming a building vulnerability class A, we therefore propose for this village an intensity of VI-VII with a quality B (fairly constrained). According to Prion (18th century) and Mercure Galant (1708), Corbières, Ste Tulle and Montfuron suffered some damage but less than Pierrevert and Manosque. In Corbières, the castle partly collapsed (A.P. Famille Allemand, Provence, 18 th century) and the church was greatly 
affected (BM Aix-en-Provence, 18th cent.), but may be due to a previous shock (AC Corbières, 1700-1709). In Ste Tulle, the wall on the square collapsed, and the wall of the cemetery, the tile works, the town hall and the chapel were repaired (AC St. Tulle, 1708-1713). In Montfuron, the cornerstones of the common house, the roof of the church, the communal oven, and the door of the cemetery were repaired (AC Montfuron, 1708-1710). These elements attest to the presence of moderate to heavy structural and nonstructural damage/repairs. For these three localities, we thus propose an intensity of VII with a quality C (poorly constrained). For Manosque and Pierrevert, although intensity estimates are the object of ongoing studies (e.g., preliminary results presented in Quenet et al., 2002), we do not anticipate major differences with the estimates provided by SISFRANCE (VIII -B).

In this study, we were able to propose intensity estimates at six localities that were not quantified previously in SISFRANCE (Montfuron, Villemus, St. Martin les Eaux, St. Michel l'Observatoire, St. Maime and Villeneuve). The spatial coherency provided by these 6 additional intensity points allows us to tentatively calculate three isoseismals VI-VII, VII, and VIII. Although the isoseismals are clearly poorly constrained (especially VI-VII which is probably only a minimum estimate), they indicate that this event is certainly a shallow event of moderate magnitude of about 5, assuming the relationship by Levret et al. (1994).

\section{Conclusions}

The main objective of this study is to provide new constraints on the damage area of the 1708 Manosque earthquake (France). First we re-interpreted existing sources in their historical context and produced a structured reference list, which served as a basis to propose a hierarchical organization of the database. We showed that the observed high spatial concentration of the narrative information could be partially explained by differences in communication about quakes and by the organisation of the territory, introducing a potential bias in historical seismicity studies.

To tackle this bias in the global perception of the event, especially affecting the rural area (Quenet, 2003), we attempted in this paper to indirectly capture the effects of the Manosque earthquake through a systematic analysis of the building repairs. This led us to examine the nonnarrative sources, until now poorly exploited. Given the spatial and temporal distribution of the repairs, we believe that the observed repairs attest to damage due to the 14 August 1708, Manosque earthquake. The valuable and complementary information documented by the analysis of building repairs resulted in new intensity estimates at six localities, extending the damage area to at least $12 \mathrm{~km}$ around Manosque.

Through this example, we showed that all the sources that a historian uses to reconstitute a natural disaster are the products of acts of communication. In this respect, non-narrative sources may provide a means of getting around the filter of individual memory and of narration that biases the reading of narrative sources, because guided by a subjective interest and a subjective communication about the catastrophe (Quenet, 2001). The results obtained thus far encourage us to pursue the research on other historical earthquakes known on the basis of only a few observation points.

\section{Acknowledgements}

We thank two anonymous reviewers and the editors for helpful comments. This research was partially funded by IRSN (IPSN/DPRE/SERGD/BERSSIN reports \# 9705, 99-43 and 01-32).

These specific studies are being carried out at IRSN and are used as complementary information to the SISFRANCE project.

\section{REFERENCES}

AC - Archives Communales (communal archives).

AD - Archives Départementales (departmental archives).

AD B. du R. - Archives Départementales des Bouches du Rhône.

AM - Archives Municipales (municipal archives)

AN - Archives Nationales (national archives).

AP - Archives Privées (private archives).

$\mathrm{BM}$ - Bibliothèque Municipale (municipal library).

BNF Paris - Bibliothèque Nationale de France (National Library of France), Paris. 
BNF, Nafr - BNF, Nouveaux Manuscrits Français (new French manuscript).

Ms - manuscript

Sources

AC Allemagne en Provence (1673-1710): Délibérations, E/43. AC Beaumont de Pertuis (1708-1710): Délibérations, BB/8. AC Beaumont de Pertuis (1708-1711): Registre paroissial. AC Brunet (1708a,b): a) Délibérations, E 35/4; b) Comptes, E $35 / 27$.

AC Corbières (1700-1709): Pièces justificatives des comptes, E 63/25.

AC Esparron de Verdon (1682-1738): Délibérations, E $81 / 4$

AC Forcalquier (1708): Déliberations, BB/43

AC Gréoux-les-Bains (1708-1709): Comptes des trésoriers, CC 13.

AC Mane (1708-1710): Délibérations.

AC Montfuron (1708-1710): Délibérations, E 128/3.

AC Niozelles (1707-1733): Délibérations, E 138/1.

AC Oraison (1708): Délibérations, E 143/3.

AC Pierrevert (1700-1739): Comptes des trésoriers, E 152/18.

AC Pierrevert (1701-1709): Pièces justificatives des comptes de 1701 à 1709, E 152/21.

AC Riez (1706-1711): Délibérations, E 166/23.

AC St. Maime (1674-1720): Délibérations, E 188/6.

AC St. Maime (1708-1710): Pièces justificatives des comptes, E 85/22.

AC St. Martin de Bromes (1708-1713): Délibérations, E $189 / 4$

AC St. Martin les Eaux (1708-1713): Délibérations, E 190/1.

AC St. Michel (1708-1712): Délibérations, E 192/14.

AC Ste Tulle (1708-1713): Comptes.

AC Ste Tulle (1709): Comptes.

AC Valensole (1708-1710): Délibérations.

AC Villemus (1708-1711): Délibérations, E 241/7.

AC Villeneuve (1708-1713): Délibérations, E 242 /10.

AD Alpes de Haute Provence (1728): Observation au sujet du nouvel affouagement, C 34.

AD B. du R. (1708-1709): Demande de dégrèvement de Manosque, C 60, f. $185 \mathrm{v}-18$.

$\mathrm{AD}$ B. du R. (1708a): Honoraires d'expertise relatifs à une enquête sur les dommages provoqués par le tremblement de terre de 1708, C 684, f. 186.

AD B. du R. (1708b): Rapport des dommages qui sont fais au lieu de Pierrevert et causés par les tramblemens de terre aux mesons fait par Jean Aubert mason et Jean Joseph Fermier maitre mason le 3 septembre 1708, C 2094.

AD B. du R. (18th cent.): Fidèle relation de tout ce qui est arrivé de plus mémorable depuis l'année 1701 par le père Pacifique, Ms. 1 J 259, f. 20-21.

AD Vaucluse (1706-1754): Livre de raison de Jean-Baptiste-Charles de Surrach, Ms., H 6 Hospice de Bédarrides.

AM Manosque (1708): Hôpital, Comptes 1708.

AM Manosque (1708-1709): Délibérations du conseil de ville, Ba 25/151.
AM Manosque (1710): Délibérations du conseil de ville, Ba 25/152.

AM Manosque (1731): Procès avec le chapitre de Forcalquier au sujet des réparations à Sainte-Sauveur, GG 20.

AN Paris (1708-1709): Correspondance adressée au contrôleur général des finances par l'intendant Le Bret, Ms. G ${ }^{7} 472$.

AP Famille Allemand, Provence (18th cent.): Récit du tremblement de terre de 1708, Ms.

AP Montesinos, Provence (18th cent.): Notes sur le tremblement de terre de Manosque de 1708 par Bouteille, Ms.

BM Aix-en-Provence (18th cent.): Relation des tremblements de terre ressentis à Manosque en 1708, Ms. 891.

BM Marseille (1666-1720): Jean-Antoine Deydier, Mémoires abrégées concernant diverses matières et ce qui s'est passé de plus remarquable depuis 1666 jusqu'en 1720, Ms. 1378, f. 94-96.

BNF Paris (1708): Annotation sur le séisme du 14 août 1708 à Marseille, Ms. Nafr. 11 221, f. 29v.

BNF Paris (1708-1709): Lettre sur le tremblement de terre de 1708 adressée à l'intendant Le Bret, Ms. Nafr.

BNF Paris (18th cent.-a): Relation des tremblements de terre arrivés à Manosque, Réserve Thoisy, Ms. 355/1883, f. 223-224.

BNF Paris (18th cent.-b): Carte allemande sur le tremblement de terre de Manosque, Département des estampes (no mark).

AnONymous (18th cent.): Tremblement de terre à Manosque, in Association Manosquine de Recherches Historiques et Naturelles, 2002, 68, 13-17.

EUROPAEISCHE (1708): Europaeische fama welche den gegenwartigen zustand der vornehmsten bose entdecket, 73.

EUROPAEISCHE (1709): Europaeische fama welche den gegenwartigen zustand der vornehmsten bose entdecket (1709), 85, 53-54.

LIVRE DE RAISON (1708-1709): Livre de raison du couvent des Capucins de Riez, edited by M.J. Maurel (1907, Digne).

MARIUS, ABBÉ (1708): Journal des tremblements de terre arrivés à Manosque, Journal de Trévoux, Mémoires pour l'histoire des sciences et des Beaux-Arts, 2094-2109.

MAYNIER, B. (1719): Histoire de la principale noblesse de Provence (Aix-en-Provence), pp. 154.

Mercure Galant (1708): Relation des tremblemens de terre arrivez le mois dernier à Manosque en Provence, Septembre, 235-242.

PRION, P. (18th cent.): Pierre Prion, scribe: mémoires d'un écrivain de campagne au XVIIIe siècle, edited by E. LE ROY LADURIE and O. RANUM (1985, Gallimard, Paris, pp. 173).

Other works

Aillaud, A. (1928): Histoire de Pierrevert (Forcalquier). Annales de la Société d'agriculture de Lyon (1845), t. VIII. BERNARD, C. (1904): Essai historique sur la ville de Forcalquier (Forcalquier)

Bernard, C. (1907): Fastes consulaires de Forcalquier. Liste chronologique des syndics, consuls, maires et 
adjoints, Annales des Basses-Alpes and Bulletin de la société scientifique et littéraire des Basses-Alpes, t. 13 347-355 and 390-395.

BM Avignon (mid 19th cent.): P. Achard, Ephémérides historiques d'Avignon et du département de Vaucluse d'après les archives départementales et municipales, Ms. 1553.

BoisliLe, A.M. DE (1897): Correspondances des contrôleurs généraux des finances (Paris), vol. 3, 47-48.

COURTET, J. (1876): Dictionnaire géographique des communes du département de Vaucluse, Avignon, 82-83.

DuboIs, P. (1979): Correspondance au BRGM du 31 octobre 1979. AP BRGM (Orléans).

DuRBEC, J.A. (1920): Les séismes en série de la région de Manosque, AP BRGM (Orléans).

Emmanuelli, F.X. (1974): Pouvoir royal et vie régionale en Provence au déclin de la monarchie. Psychologie, pratique administrative, défrancisation de l'intendance d'Aix (1745-1790), Lille (service de reproduction des thèses).

FERAUD, A. (1848): Histoire civile, politique, religieuse et biographique de Manosque (Digne), 311-318.

FERRAND, J.J.M. (1861): Histoire géologique et statistique du département des Basses-Alpes (Digne), 568-569.

GRÜNTHAL G. (Editor) (1998): European Macroseismic Scale 1998 (EMS-98), in Cahiers du Centre Européen del Gèodinamique et de Séismologie (Luxembourg), 15, pp. 99.

HofF, K.E.A. von (1840-1841): Chronik der Erdbeben und Vulcan-Ausbrüche, I. Theil (Justus Perthes, Gotha), pp. 470; II. Theil (Justus Perthes, Gotha), pp. 406.

Indicateur de la ville d'Aix pour l'année 1826, suivi de la revue de l'année 1825 pour la ville d'Aix (1827), Aix, p. 47.

Journal des Basses Alpes (1876), 24 septembre.

LAMBERT, J. (1988): Révision de sismicité historique, in Les tremblements de terre de 1509 et 1708 dans la moyenne vallée de la Durance (Éditions du BRGM, Orléans), 15-88.

Lambert, J., P. Bernard, G. Czitrom, J.Y. Dubié, P. GoDEFroY and A. LEVRET-AlBARET (1997): in Les tremblements de terre en France: hier, aujourd'hui, demain (Éditions du BRGM, Orléans), p. 196.

LeVret, A. and G. Quenet (1999): Le séisme de 1708 dans la région de Manosque, recherche de sources et études du contexte, Rapport IPSN 99/43, Octobre 1999.

Levret, A., J.C. BaCKe and M. Cushing (1994): Atlas of macroseismic maps for French earthquakes with their principal characteristics, Natural Hazards, 10, 19-46.

MaIRE DE Pierrevert (1981): Correspondance au BRGM du 31 juillet 1981 (AP BRGM, Orléans).

Mariotti, D., A. Comastri and E. Guidoboni (2000): «Unknown» earthquakes: a growing contribution to the catalogue of Strong Italian Earthquakes, Ann. Geofis., 43 (4), 787-795.

Maurel, M.-J. (1925a): Les deux séminaires du diocèse de Sisteron (Digne), 34-35.

Maurel, M.-J. (1925b) : Toutes Aures, in annales des Basses-Alpes, Bulletin de la société scientifique et littéraire des Basses-Alpes (Digne), t. 20.
Messager de Provence (1863), 16 juillet.

Montandon, F. (1953): Les Tremblements de Terre Destructeurs en Europe (Genève), pp. 195.

Nature (1876), 10 mai.

Perrey, A. (1845): Mémoires sur les tremblements de terre ressentis en France, Belgique et Hollande, depuis le quatrième siècle de l'ère chrétienne jusqu'à nos jours (1843 inclus) (Bruxelles).

QuenET, G. (2001): Les tremblements de terre en France XVIIe-XVIIIe siècles. Une histoire sociale du risque, Thèse de l'Université Paris I, sous la dir. de D. ROCHE.

QuENET, G. (2002): Les apports de la critique historique à la sismicité historique, in Actes des $V^{\circ}$ Rencontres du Groupe APS 2000: "Archéosismicité et Sismicité Historique», edited by R. MARICHAL (Perpignan), 91105.

QuENET, G. (2003): La catastrophe aux champs. Espaces ruraux et tremblements de terre en France aux xviie et xviiie siècles, in Enquêtes Rurales, Cahiers de la Maison de la Recherche en Sciences Humaines, 9, 82102.

Quenet, G., A. Levret, O. Scotti, D. Baumont and G. Poursoulis (2002): The 1708 Manosque seismic sequence (France), a multi-disciplinary approach and application of the EMS, in XXVIII General Assembly of the ESC Meeting, Gènes.

RIDEAUD, A. (1998): Traces de séismes dans le bâti ancien de la Moyenne Durance. Le village de Beaumont de Pertuis, Rapport IRSN.

Rideaud, A. and A. LEVRET (2000): Traces de séismes historiques sur le bâti ancien en moyenne Durance : Beaumont-de-Pertuis, in Actes des $I V^{\circ}$ Rencontres $d u$ Groupe APS 1999: "Archéosismicité et Vulnérabilité du Bâti Ancien», edited by R. MARIchal (Perpignan), 39-64.

RoBerT, J.M. (1812): Notice historique sur le tremblement de terre du village de Beaumont (Aix-en-Provence), 136

RotHÉ, J.-P. (1941): Les séismes des Alpes françaises en 1838 et la sismicité des Alpes occidentales, in Annales 1938 (Institut physique du Globe de Strasbourg, Mende), vol. 3, 1-105.

Scotti, O., D. Baumont, G. Quenet, and A. LeVret (2004): The French Macroseismic Database SISFRANCE: objectives, results and perspectives, Ann. Geophysics, 47 (2-3), 571-581 (this volume).

SEYFART, J.-F. (1756): Allgemeine geschichte der erdbeben (Leipzig).

Veyne, P. (1979): Comment on écrit l'histoire (Paris, Seuil).

Vogt, J. (1981): Les séismes notables de la moyenne Durance. Mise au point de sismicité historique (CEA, Fontenay-aux-Roses).

Vogt, J. (1993): Coup d'oeil à la sismicité historique de la moyenne vallée de la Durance in Géomorphologie et aménagement de la Montagne (Hommage à P. Gabert, CNRS, Caen), 223-229 